\title{
Introduksi Pakan Basal dan Indigofera untuk Meningkatkan Performa Kambing di Kabupaten Bireun
}

\section{Introduction of Basal and Indigofera Feed to Improve Goat Performance in Bireun District}

\author{
Y. Yusriani ${ }^{1 *}$, R. Andriani ${ }^{1}$, dan M. Sabri ${ }^{2}$ \\ ${ }^{1}$ Balai Pengkajian Teknologi Pertanian, Aceh - Indonesia \\ ${ }^{2}$ Fakultas Kedokteran Hewan, Universitas Syiah Kuala, Aceh - Indonesia \\ *Corresponding E-mail: yenniyusriani@ymail.com \\ (Diterima: 10 April 2020; Disetujui: 7 Juli 2020)
}

\begin{abstract}
ABSTRAK
Penelitian telah dilaksanakan di desa Keudee Dua, Kecamatan Juli, Kabupaten Bireun pada tahun 2016. Penelitian ini menggunakan Rancangan Acak Kelompok dengan 3 perlakuan dan 3 ulangan. $\mathrm{P} 1=$ Pakan basal $30 \%$ + indigofera $70 \%, \mathrm{P} 2=$ Pakan basal 50\% + indigofera $50 \%$, dan P3 $=$ Pakan basal $70 \%$ + indogofera $30 \%$. Ternak yang digunakan yaitu ternak kambing sebanyak 15 ekor. Ternak mendapatkan suplementasi konsentrat terlebih dahulu, setelah habis baru diberikan pakan basal, sedangkan air minum diberikan ad-libitum. Pengamatan dilakukan selama 4 bulan dengan masa adaptasi 2 minggu. Teknik pengambilan sampel responden dilakukan sebanyak 30 orang peternak melalui metode survei dan kuesioner. Data yang dikumpulkan meliputi: kondisi geografis dan agrofisik wilayah, pertambahan bobot badan harian, karakteristik peternak, dan manajemen pemberian pakan. Data yang dikumpulkan diolah secara tabulasi dan dianalisis secara deskriptif. Hasil penelitian menunjukkan bahwa pertambahan bobot badan (PBBH) ternak kambing berkisar antara 51,83 sampai 57,00. PBBH ternak kambing yang diberi ransum P3 lebih tinggi dibandingkan P1 dan P2, meski tidak berbeda nyata. Untuk karakteristik dan manajemen pemberian pakan, peternak terbuka dalam menerima inovasi yang diajarkan. Pengetahuan dan sikap petani peternak dalam menerima teknologi inovatif sangat baik sehingga pemanfaatan pakan lebih efisien di lokasi.
\end{abstract}

Kata kunci: pemanfaatan pakan, performa kambing, teknologi, inovasi

\section{ABSTRACT}

The study was carried out in Keudee Dua village, Juli sub-district, Bireun Regency, in 2016. This study used a Randomized Block Design with three treatments, three replications: P1. Basal feed 30\% + Indigofera $70 \%, P 2.50 \%$ basal feed $+50 \%$ Indigofera, P3. $70 \%$ basal feed $+30 \%$ Indigofera. There are as many as 15 goats. Livestock received concentrate supplementation first after being given basal feed, while drinking water is given ad-libitum. Observation is carried out for four months, with an adaptation period of 2 weeks. Thirty farmers do the respondent sampling technique through survey and questionnaire methods. Data collected includes geographical and agrophysical conditions of the region, daily weight gain, characteristics of breeders and, feed management. Data collected were tabulated and analyzed descriptively. The results showed that the weight gain (PBBH) of goats ranged from 51.83 to 57.00. PBBH for goats given $P 3$ ration was higher than P1 and P2, although it was not significantly different. For the characteristics and management of feeding, farmers are open to accepting the innovations that are taught. Knowledge and attitudes of farmers in receiving innovative technology are perfect so that the utilization of feed is more efficient at the site.

Keywords: feed utilization, goat performance, technology, innovation 


\section{PENDAHULUAN}

Secara umum Kabupaten Bireuen mempunyai potensi yang dapat mendukung upaya pengembangan peternakan dengan tersedianya ketersediaan hijauan pakan ternak yang belum dioptimalkan untuk usaha ternak kambing yaitu lahan yang tersedia dan dari hasil samping pertanian (Yusriani et al., 2018). Kecamatan Juli, mempunyai luas kecamatan 21,208 $\mathrm{km}^{2}$, dengan luas lahan pertanian $15,936 \mathrm{~km}^{2}$ yang merupakan salah satu penghasil sektor pertanian terutama kedelai dan memiliki potensi pengembangan peternakan. Penyediaan hijauan yang baik dalam kualitas maupun kuantitas dapat meningkatkan produksi ternak kambing. Untuk melengkapi unsur nutrisi yang diperlukan oleh ternak kambing dibutuhkan pakan hijauan yang terdiri dari rumput dan legume. Hijauan merupakan sumber pakan utama untuk untuk meningkatkan produksi ternak kambing. Nilai nutrient yang dikonsumsi oleh ternak diharapkan menjadi sumber protein dalam meningkatkan produktivitas ternak ruminansia (Koten et al, 2014).

Jerami kedelai (Glycine max L. Merr.) merupakan salah satu limbah tanaman pangan di Kabupaten Bireun hasil samping tanaman kedelai sangat potensial untuk dijadikan sebagai pakan yang sampai saat ini belum dimanfaatkan secara optimal sebagai sumber protein. Sebagian kecil dari bungkil digunakan untuk membuat tepung kedelai rendah lemak, konsentrat protein kedelai dan isolat, dan produk protein bertekstur kedelai. Jerami kedelai mengandung fitoestrogen (senyawa estrogen yang berasal dari tanaman) sebesar 0,498 -1,748 g/100 g (Tiro, 2010) dan mempunyai kandungan protein yang cukup tinggi 14,45\% (Tiro, 2012).

Daun gamal berbentuk elips (oval), ujung daun lancip dan pangkalnya tumpul (bulat), susunan daun terletak berhadapan seperti daun lamtoro atau turi. Pada musim kemarau muncul bunga gamal yang berbentuk kupu-kupu terkumpul pada ujung batang
(Natalia et al., 2009). Pemberian daun gamal sebaiknya bersama-sama dengan pemberian rumput. Hijauan pakan yang tersedia meliputi jenis hijauan seperti gamal memiliki keunggulan yang dibutuhkan oleh ternak yaitu protein asam amino esensial, vitamin serta mineral namun belum banyak dimanfaatkan oleh peternak (Marhaeniyanto et al., 2019).

Salah satu jenis rumput yang dapat dijadikan sebagai sumber hijauan adalah Rumput Gajah (Pennisetum purpureum). Keuntungan dalam usaha peternakan dapat dilihat dari kualitas hijauan yang diberikan dan memiliki efek pada ternak (Purbajanti et al., 2013). Untuk mendapatkan produksi hijauan kualitas tinggi akan sulit dicapai dibandingkan dengan produksi hijauan dengan kualitas rendah (Blezinger, 2013), kandungan protein kasar sekitar 13,3 - 13,9\% (Wijitphan et al., 2009), namun tetap membutuhkan perawatan yang intensif. Zhang et al. (2010) menambahkan tinggi produksi mempunyai korelasi positif terhadap ciri morfologi seperti tinggi tanaman, panjang daun dan lebar daun tanaman rumput gajah.

Tanaman lndigofera sp. merupakan tanaman leguminosa pohon yang belum banyak di eksplorasi yang kaya akan protein, kalsium dan fosfor. Nilai nutrisi lndigofera sp. berumur I tahun dengan interval pemotongan 3 bulan mengandung protein kasar rata-rata $23,20 \%$, bahan organik $90,68 \%$, NDF $36,72 \%$, fosfor $0,83 \%$ dan kalsium $1,23 \%$ (Nurhayu et al., 2016). Keunggulan indigofera dengan legume yang lain yaitu memiliki keunggulan dalam produksi dan kualitas hijauannya yang lebih baik (Abdullah, 2014). Tanaman indigofera kurang disukai oleh ternak sehingga dalam pemanfaatannya belum banyak direkomendasikan sebagai pakan (Krisnan et al., 2012).

Langkah yang tepat untuk mengurangi keterbatasan pakanadalah denganpemanfaatan hijauan dan bahan baku lokal yang tersedia di lokasi. Tujuan penulisan makalah untuk melihat potensi dan pemanfaatan introduksi pakan dengan penambahan indigofera dengan harapan dapat memberikan peningkatan 
efisiensi pakan melalui strategi suplementasi pakan untuk meningkatkan performa ternak kambing serta melihat tingkat pengetahuan dan sikap peternak terhadap teknologi inovasi yang diberikan selama penelitian berlangsung.

\section{METODE PENELITIAN}

\section{Materi}

Materi yang digunakan adalah ternak kambing, hijauan asal limbah pertanian berupa jerami kedelai dan hijauan berupa daun gamal, rumput gajah (pakan basal) dan indigofera (konsentrat).

\section{Metode}

Penelitian ini menggunakan dua tahapan yaitu dengan pemberian pakan untuk mengetahui performa ternak kambing serta metode kuesioner untuk mengetahui tingkat pengetahuan dan sikap peternak dalam menerima teknologi inovasi yang diberikan.

Ternak kambing betina yang digunakan sebanyak 15 ekor berumur 9-12 bulan. Pakan basal yang diberikan kepada ternak kambing berupa jerami kedelai, daun gamal, rumput gajah dengan perbandingan 1:1:1. Pada penelitian ini menggunakan Rancangan Acak Kelompok dengan 3 perlakuan, 3 ulangan: P1 = Pakan basal 30\% + indigofera $70 \%, \mathrm{P} 2=$ Pakan basal $50 \%+$ indigofera $50 \%, \mathrm{P} 3=$ Pakan basal 70\% + indogofera $30 \%$. Pembuatan pakan dilakukan dengan cara mencacah dengan menggunakan mesin cooper, kemudian dicampur dan ditimbang sesuai dengan perlakuan, pemberian pakan dilakukan 2 kali sehari yaitu pada pagi hari pukul 08:00 WIB dan pada sore hari pukul 17:00 WIB. Yusmadi (2008) melaporkan jumlah pakan yang diberikan sebesar $4 \%$ dari bobot badan dalam bentuk segar. Pakan yang diberikan akan dikurangkan dengan pakan sisa sebagai perhitungan dari konsumsi pakan dan konversi pakan. Penimbangan ini dilaksanakan selama empat bulan pada semua kambing yang dikaji. Pakan diberikan secara terpisah antara pakan basal dan konsentrat. Ternak mendapatkan suplementasi konsentrat terlebih dahulu, setelah habis baru diberikan pakan basal sedangkan air minum diberikan ad-libitum.

Teknik pengambilan sampel responden dilakukan secara acak sebanyak 30 orang petani/peternak melalui metode survei dan kuesioner. Kajian ini dilaksanakan dengan mengintegrasikan pendekatan kuantitaif dan kualitatif. Metode kuantitiatif dilakukan dengan menyiapkan pertanyaan terstruktur (kuesioner) terkait kondisi geograrafis dan Agrofisik wilayah, karakteristik petani, manajemen pakan, kondisi sosial, ekonomi, dan budaya lokal. Sedangkan pendekatan kualitatif dilakukan untuk mendalami subjective meaning dari masyarakat petani lokal dengan menetapkan daftar pertanyaan pengarah, untuk menangkap secara mendalam kebutuhan masyarakat. Data yang dikumpulkan diolah secara tabulasi dan dianalisis secara deskriptif.

\section{HASIL DAN PEMBAHASAN}

\section{Kondisi Geografis dan Agrofisik Lokasi}

Secara geografis, Kabupaten Bireuen terletak pada posisi $4^{\circ} 54^{\prime}-5^{\circ} 21^{\prime}$ Lintang Utara (LU) dan 96 $20^{\prime}-97^{\circ} 21^{\prime}$ Bujur Timur (BT) dengan luas wilayahnya $1.901,21 \mathrm{Km}^{2}$ atau (190.121 ha) dan berada pada ketinggian 0 sampai 800 meter dari permukaan laut (DPL). Topografi Kabupaten Bireuen terdiri dari pantai dengan dataran rendah di sebelah Utara dan daerah pegunungan di sebelah selatan. Luas tanah menurut penggunaannya terdiri dari 17.172 $\mathrm{Ha}$ perkampungan, $22.948 \mathrm{Ha}$ persawahan, 34.013 Ha tegalan, $37.994 \mathrm{Ha}$ perkebunan rakyat, 5.194 Ha tambak, 5.952 Ha berupa semak/alang-alang, 4.642 Ha hutan belukar, 32.286 Ha tebat, 2.072 Ha kebun campuran, $965 \mathrm{Ha}$ perkebunan besar, $564 \mathrm{Ha}$ danau dan rawa.

Pengembangan peternakan akan berjalan lambat apabila masih menggunakan sistem pemeliharaan tradisional terhadap perekonomian suatu daerah. Perlu adanya perubahan strategi peningkatan populasi 
Tabel 1. Rataan bobot hidup awal, bobot hidup akhir, kenaikkan bobot hidup, PBHH selama perlakuan

\begin{tabular}{lcccc}
\hline Perlakuan & $\begin{array}{c}\text { Bobot hidup awal } \\
(\mathrm{kg})\end{array}$ & $\begin{array}{c}\text { Bobot hidup akhir } \\
(\mathrm{kg})\end{array}$ & $\begin{array}{c}\text { Kenaikan bobot } \\
\text { hidup }(\mathrm{kg})\end{array}$ & $\begin{array}{c}\text { PBBH } \\
(\mathrm{kg})\end{array}$ \\
\hline P1 & 18,21 & 24,55 & 6,34 & $52,83^{\mathrm{a}}$ \\
P2 & 17,58 & 23,80 & 6,22 & $51,83^{\mathrm{a}}$ \\
P3 & 16,92 & 23,76 & 6,84 & $57,00^{\mathrm{a}}$ \\
\hline
\end{tabular}

Keterangan: Angka yang diikuti oleh huruf yang sama menunjukkan tidak berbeda nyata $(\mathrm{P}>0,05)$. $\mathrm{P} 1=$ Pakan basal $30 \%+$ indigofera $70 \%, \mathrm{P} 2=$ Pakan basal $50 \%+$ indigofera $50 \%, \mathrm{P} 3=$ Pakan basal $70 \%+$ indogofera $30 \%$.

ternak. Dalam usaha peternakan ada beberapa aspek yang harus diperhatikan yaitu perbaikan manajemen pemeliharaan meliputi sistem perkandangan, pemanfaatan hasil samping tanaman dan upaya untuk antisipasi keberlanjutan dengan penanaman tanaman yang dapat dijadikan sebagai pakan ternak.

\section{Pertambahan Bobot Badan}

Pemeliharaan semi intensif ditandai dengan adanya peningkatan produksi pada bobot hidup kambing. Hasil penimbangan ternak setiap dua minggu menunjukkan bahwa pemberian pakan basal + indigofera memperlihatkan adanya peningkatan bobot hidup kambing. Hal ini dapat dilihat pada akhir kegiatan pengkajian menunjukkan bahwa semua perlakukan (P1, P2, dan P3) mengalami kenaikkan bobot hidup akhir (Tabel 1). Ali et al. (2017) menyatakan bahwa pertambahan berat badan merupakan kemampuan ternak dalam mengubah zat - zat nutrisi yang ada dalam pakan menjadi daging/ otot.

Hasil analisis statistik menunjukkan bahwa pemberian pakan basal + indigofera tidak berpengaruh nyata $(\mathrm{P}>0,01)$ terhadap rataan PBHH kambing (Tabel 1), hal tersebut karena bobot anak kambing yang digunakan dalam penelitian ini relatif seragam. Pertumbuhan pada umumya dinyatakan dengan mengukur kenaikan berat badan dan biasanya dinyatakan sebagai pertambahan berat badan (PBB) harian. Pertambahan bobot badan (PBB) harian ternak kambing berkisar antara 51,83 sampai 57,00 (Tabel 1). PBB harian anak kambing yang diberi ransum P3 lebih tinggi dibandingkan P1 dan P2, meski tidak berbeda nyata.

\section{Karakteristik Peternak di Lokasi}

Profil peternak kambing pada kelompok Awee Teubee memperlihatkan umur responden menunjukkan sebagian besar peternak berusia 31- 40 tahun dengan jenis kelamin paling banyak adalah laki laki (Tabel 2). Berdasarkan hasil penelitian yang telah dilakukan bahwa jumlah petani yang terbanyak yaitu sebagian besar berada pada kategori usia produktif. Karena usia produktif berada pada kategori umur 31 - 40 tahun dengan potensi yang dimiliki dalam mengakses segala bentuk informasi yang diperoleh untuk mengadopsi inovasi yang diberikan. Produktivitas seseorang dalam bekerja sangat dipengaruhi oleh faktor umur. Umur, pendidikan, pengalaman, dan jumlah ternak mempengaruhi perilaku seseorang dalam beternak (Mulyati et al., 2016). Peternak yang masih muda akan lebih cepat melakukan adopsi inovasi karena memiliki semangat dan keinginan untuk mengetahui apa yang belum diketahui dalam uasaha peternakan.

Tingkat pendidikan responden dianggap dapat memengaruhi sikap hidup seseorang terhadap lingkungannya. Pendidikan yang tinggi mengakibatkan peternak lebih dinamis. Hal ini dikuatkan di lapangan bahwa teknologi yang diterapkan akan mudah dimengerti dengan tingginya pendidikan peternak serta penerapannya dengan baik. Sari (2014) melaporkan bahwa tingkat pendidikan juga berpengaruh dalam kemampuan berfikir sehingga akan mempengaruhi pengembangan 
Tabel 2. Profil Peternak Kambing Responden

\begin{tabular}{clcc}
\hline No & Profil Peternak & Jumlah Orang $(\mathrm{n}=30)$ & Persentase $(\%)$ \\
\hline 1 & Umur: & 4 & \\
& 20-30 tahun & 18 & 13,3 \\
& $31-40$ tahun & 5 & 60,0 \\
& $41-50$ tahun & 3 & 16,7 \\
& $>51$ tahun & & 1,0 \\
\hline 2 & Jenis kelamin: & 26 & 86,7 \\
& Laki-laki & 4 & 13,3 \\
& Perempuan & & \\
\hline 3 & Pendidikan: & 2 & 0,6 \\
& Tidak sekolah & 4 & 13,3 \\
& SD & 10 & 33,3 \\
& SMP & 24 & 0,8 \\
& SMA & & \\
\hline 4 & Pekerjaan: & 20 & 66,7 \\
& Petani peternak & 10 & 33,3 \\
& Pedagang & & \\
\hline 5 & Pengalaman beternak: & 5 & 73,7 \\
& $<5$ tahun & 22 & 1,0 \\
\hline 5-25 tahun & 3 & \\
& $>25$ tahun & &
\end{tabular}

Sumber: data primer diolah, 2017

dan peningkatan taraf hidup. Selanjutnya Murwanto (2008) bahwa indikator kualitas penduduk merupakan peubah kunci dalam pengembangan sumber daya manusia adalah tingkat pendidikan peternak. Faktor pendidikan sangat diharapkan dalam usaha peternakan agar membantu masyarakat dalam upaya peningkatan produksi dan produktivitas ternak yang dipelihara atau diternakkan.

Persentase pekerjaan peternak sebesar $66,7 \%$. Hal ini memperlihatkan peternak lebih fokus pada beternak kambing sehingga memudahkan dalam penyampaian teknologi inovasi yang diberikan. Pengalaman beternak mempunyai pengaruh terhadap adopsi teknologi pemeliharaan kambing, semakin tinggi pengalaman beternak maka akan semakin tinggi tingkat adopsi teknologi pemeliharaan kambing. Peternak mempunyai pengalaman yang banyak, tentu akan mempunyai pengetahuan yang tinggi tentang seluk beluk beternak kambing dan teknologi yang sesuai untuk pengembangan usaha peternakan kambing. Idris et al. (2009) menyatakan dimana peternak yang mempunyai pengalaman akan lebih cepat menganalisis inovasi. Semakin lama pengalaman beternak akan membawa dampak positif untuk mengembangkan usaha peternakan berdasarkan minat yang dimiliki dan tidak ragu-ragu untuk menerapkannya jika sudah yakin manfaatnya.

Keberhasilan peternak dalam meningkatkan pengembangan usaha ternak dan pendapatan sangat ditentukan oleh pengalaman beternak peternak. Semakin banyak pengalaman beternak akan membuat peternak lebih cermat dalam berusaha dan dapat memperbaiki kekurangan di masa lalu (Murwanto, 2008), sehingga peternak mampu mengatasi permasalahan yang ada di lapangan. Umur dan pengalaman beternak akan mempengaruhi kemampuan peternak dalam menjalankan usaha ternak kambing. Peternak akan lebih mudah mengatasi kesulitan yang dialami dengan mempunyai pengalaman yang 
Tabel 3. Gambaran umum Budidaya Ternak Kambing

\begin{tabular}{|c|c|c|}
\hline No. & Komponen & Identifikasi \\
\hline 1 & $\begin{array}{l}\text { Sistem pemeliharaan ternak: } \\
\text { Intensif } \\
\text { Semi intensif } \\
\text { Extensif }\end{array}$ & $\begin{array}{c}\text { Tidak ada } \\
\text { 100\% peternak melakukan sistem pemeliharaan semi } \\
\text { intensif } \\
\text { Tidak ada }\end{array}$ \\
\hline 2 & $\begin{array}{l}\text { Perkandangan: } \\
\text { Pengetahuan perkandangan } \\
\text { kambing } \\
\text { Jenis kandang } \\
\text { Bahan kandang }\end{array}$ & $\begin{array}{l}\text { Kandang panggung } \\
\text { Kandang individu } \\
\text { Kayu, bambu, atap rumbia }\end{array}$ \\
\hline 3 & $\begin{array}{l}\text { Status kepemilikan: } \\
\text { Milik sendiri } \\
\text { Gaduhan }\end{array}$ & $\begin{array}{l}100 \% \text { kepemilikan sendiri } \\
\text { Tidak ada }\end{array}$ \\
\hline 4 & $\begin{array}{l}\text { Sistem beternak: } \\
\text { Perorangan } \\
\text { Kelompok/koperasi }\end{array}$ & $\begin{array}{c}\text { Tidak ada } \\
\text { Sistem beternak dengan kelompok }\end{array}$ \\
\hline 5 & $\begin{array}{l}\text { Transporatsi: } \\
\text { Sepeda motor } \\
\text { Jalan kaki }\end{array}$ & $\begin{array}{l}100 \% \text { peternak menggunakan sepeda motor } \\
\text { Tidak ada }\end{array}$ \\
\hline
\end{tabular}

Sumber: data yang diolah, 2017

lama dalam beternak.

Gambaran umum budidaya ternak kambing yaitu mayoritas peternak kambing di lokasi penelitian telah mengetahui cara dan pola budidaya ternak, meskipun dasar budidaya tersebut adalah pengalaman dan tradisi yang dibawa dari generasi ke generasi (Tabel 3). Peternak terbuka dalam menerima inovasi yang diajarkan. Dalam menerima teknologi inovatif yang diberikan, pengetahuan dan sikap peternak sangat baik (Yusriani et al., 2017).

Sistem pemeliharaan yang dilakukan pada kegiatan semi intensif yaitu ternak dibiarkan di umbaran pada pagi hari dan sore hari ternak dikandangkan. Sistem perkandangan yang sering digunakan adalah sistem panggung karena mempunyai beberapa kelebihan yaitu memudahkan dalam pengambilan kotoran, sanitasi kandang serta pembersihan dan pemberian pakan secara bersamaan dalam kandang dari sisa pakan sebelumnya (Suherman dan Kurniawan,
2017). Sistem pemeliharaan semi intensif merupakan penggabungan sistem ekstensif dan penggembalaan sistem intensif dengan penggembalaan terkontrol dan pemberian konsentrat. Para peneliti telah melaporkan untuk mengantisipasi dampak negatif suhu udara tinggi dan cekaman panas dalam kandang, seperti penggunaan naungan/atap, penyiraman air, penggunaan kipas angin dengan menggunakan teknik modifikasi lingkungan iklim (Embertson et al., 2009).

Status kepemilikan ternak sebesar 100 persen merupakan milik sendiri. Tingginya persentase kepemilikan menunjukkan bahwa kesadaran peternak akan pentingnya ternak kambing sebagai tabungan dalam keluarga. Keunggulan pola budidaya ternak di lokasi penelitian menggambarkan peternak sudah mengetahui pola budidaya yang baik dan benar yang didasarkan oleh pengalaman beternak dan kepemilikan ternaknya sendiri dengan sistem beternak secara kelompok dan masuk dalam anggota koperasi. 
Tabel 4. Manajemen Pemberian Pakan

\begin{tabular}{|c|c|c|}
\hline Manajemen Pemberian Pakan & Jumlah responden $(\mathrm{n}=30)$ & Persentase $(\%)$ \\
\hline $\begin{array}{l}\text { Perolehan pakan dari: } \\
\text { Tegalan } \\
\text { Sawah } \\
\text { Penanaman sendiri }\end{array}$ & $\begin{array}{c}1 \\
5 \\
24\end{array}$ & $\begin{array}{c}0,3 \\
16,7 \\
80,0\end{array}$ \\
\hline $\begin{array}{l}\text { Pakan yang diberikan berasal dari: } \\
\text { Pabrik } \\
\text { Pakan buatan sendiri } \\
\text { Konsentrat }\end{array}$ & $\begin{array}{c}2 \\
25 \\
3 \\
\end{array}$ & $\begin{array}{c}0,6 \\
83,0 \\
1,0 \\
\end{array}$ \\
\hline $\begin{array}{l}\text { Ketersediaan pakan: } \\
\text { Kurang } \\
\text { Cukup } \\
\text { Banyak }\end{array}$ & $\begin{array}{c}3 \\
24 \\
3\end{array}$ & $\begin{array}{l}1,0 \\
8,0 \\
1,0\end{array}$ \\
\hline $\begin{array}{l}\text { Pemanfaatan limbah pertanian: } \\
\text { Kurang } \\
\text { Cukup } \\
\text { Banyak }\end{array}$ & $\begin{array}{c}2 \\
26 \\
2\end{array}$ & $\begin{array}{c}0,6 \\
86,0 \\
0,6\end{array}$ \\
\hline $\begin{array}{l}\text { Kendala yang dihadapi dengan pakan: } \\
\text { Ketersediaan pakan } \\
\text { Harga pakan } \\
\text { Kualitas pakan }\end{array}$ & $\begin{array}{l}30 \\
30 \\
30\end{array}$ & $\begin{array}{l}100,0 \\
100,0 \\
100,0\end{array}$ \\
\hline $\begin{array}{l}\text { Pakan: } \\
\text { Pengetahuan pakan kambing } \\
\text { Jumlah pakan yang diberikan } \\
\text { Ketersediaan pakan }\end{array}$ & $\begin{array}{l}30 \\
30 \\
30\end{array}$ & $\begin{array}{l}100,0 \\
100,0 \\
100,0\end{array}$ \\
\hline $\begin{array}{l}\text { Sistem pemberian pakan: } \\
\text { Merumput di umbaran } \\
\text { Merumput di sawah } \\
\text { Merumput di umbaran dan diberi rumput } \\
\text { potongan }\end{array}$ & $\begin{array}{c}0 \\
0 \\
30\end{array}$ & $\begin{array}{c}0,0 \\
0,0 \\
100,0\end{array}$ \\
\hline
\end{tabular}

Sumber: data primer yang diolah, 2017

Jumlah kepemilikan adalah besar kecilnya skala usaha berdasarkan jumlah ternaknya. Di pedesaan kisaran pemilikan ternak kambing 3-7 ekor ekor/peternak dengan skala usaha sambilan dengan sistem pemeliharaan dibiarkan begitu saja berkembang biak dan dapat dijual apabila ada kebutuhan uang (Budiarsana et al., 2003). Untuk mempermudah responden digunakan transportasi sepeda motor dalam mengambil pakan (Marhaeniyanto, 2017).

\section{Manajemen Pemberian Pakan}

Manajemen pemberian pakan pada kelompok Awee Tabeeu menunjukkan bahwa sumber pakan diperoleh dari penanaman yang ada di lokasi kegiatan yang sebagian berfungsi sebagai pagar mencapai 80\% (Tabel 4). Hal ini dapat mendukung pertumbuhan hijauan karena pergantian pemotongan rumput. Terbatasnya ketersediaan pakan saat musim kemarau, responden mengalami kesulitan dalam mencari pakan sehingga memanfaatkan limbah pertanian tanaman kedelai sebagai pakan. Ketersediaan pakan mengandalkan tanaman yang ditanam di lokasi penelitian. Sebelum diberikan kepada ternak, 
pakan ditimbang terlebih dahulu sesuai berat badan ternak. Pakan hijauan yang diberikan pada ternak berasal dari lahan masing-masing peternak dengan sistem merumput diumbaran dan sore hari pakan yang telah dipotong diberikan di dalam kandang.

Jenis hijauan yang diberikan berasal dari tumbuhan dan daun-daunan yang dapat digunakan sebagai pakan. Pemberian pakan dilakukan saat menjelang sore hari, dimana peternak menyediakan pakan saat pulang. Selain gamal, tanaman yang tersedia di lokasi tanaman kedelai, rumput gajah dan indigofera. Hasil penelitian menunjukkan bahwa penggunaan produk hasil samping pertanian yang palatabilitasnya rendah, dapat ditingkatkan secara nyata melalui teknologi pakan komplit yang mempunyai manfaat dilihat dari aspek potensi sumber daya lokal berupa bio masa bahan pakan inkonvensional seperti hasil samping/ sisa pertanian maupun industri-agro. Potensi ini sangat besar, baik dalam jumlah maupun keragaman jenisnya sebagai pakan alternatif (Ginting, 2009).

\section{KESIMPULAN}

Pertambahan bobot badan (PBBH) ternak kambing berkisar antara 51,83 sampai 57,00 . PBBH ternak kambing yang diberi ransum $\mathrm{P} 3$ lebih tinggi dibandingkan $\mathrm{P} 1$ dan P2, meski tidak berbeda nyata. Untuk karakteristik dan manajemen pemberian pakan, peternak terbuka dalam menerima inovasi yang diajarkan. Pemanfaatan pakan lebih efisien di lokasi sehingga diterima dengan baik karena peternak mempunyai pengetahuan dan sikap dalam menerima teknologi inovatif.

\section{DAFTAR PUSTAKA}

Abdullah. 2014. Prospektif Agronomi dan Ekofisiologi Indigofera zollingeriana Sebagai Tanaman Penghasil Hijauan Pakan Berkualitas Tinggi. Jurnal Pastura. 3(2): 79 -83.
Ali, A., Munawarah, N. dan Sofyan, N. 2017. Pengaruh Pemberian Ampas Tahu Terhadap Produksi Air Susu dan Pertambahan Berat Badan Kambing Peranakan Etawa (PE). Jurnal Saintek Peternakan dan Perikanan. 1(1): 23-26.

Blezinger, S. 2013. Forage Ouality. Digestibility Play an Important Role in "Cattle Production. The Brahman Journal, Texas.

Embertson, M. N. M., Robinson, P. H., Fadel, J. G. and Mitloehner, F. M. 2009. Effects of Shade and Sprinklers on Performance, Behavior, Physiology, and The Environment of Heifers. J. Dairy Sci. 92: 506-517.

Idris, N., H. Afriani, dan Fatati. 2009. Minat Peternak Untuk Mengembangkan Ternak Sapi di Kawasan Perkebunan Kelapa Sawit (Studi Kasus: Kecamatan Sungai Bahar Kabupaten Muaro Jambi). Jurnal Penelitian Universitas Jambi Seri Humaniora, 11(2): 1-0.

Krisnan, R., J. Sirait., A. Tarigan, dan K. Simanuhuruk. 2012. Indigofera sebagai Pakan Ternak. Pusat Penelitian dan Pengembangan Peternakan. Badan Litbang Pertanian. Kementerian Pertanian. IAARD Press.

Koten, B. B., Wea, R., Soetrisno, R. D., Ngadiyono, N. dan Soewignyo, B. 2014. Konsumsi Nutrien Ternak Kambing yang Mendapatkan Hijauan Hasil Tumpangsari Arbila (Phaseolus lunatus) dengan Sorgum sebagai Tanaman Sela pada Jarak Tanam Arbila dan Jumlah Baris Sorgum yang Berbeda. Jurnal Ilmu Ternak. 1(8): 3845 .

Marhaeniyanto, E. dan Susanti, S. 2017. Penggunaan Daun Gamal, Lamtoro, Kaliandra, dan Nangka Dalam Konsentrat Untuk Meningkatkan Penampilan Kambing Pejantan Muda. Seminar Nasional Hasil Penelitian Universitas Kanjuruhan Malang.

Marhaeniyanto, E., Susanti, S., Siswanto, B. 
dan Murti, A. T. 2019. Inventarisasi Pemanfaatan Daun Tanaman Sebagai Sumber Protein Dalam Pakan Kambing Peranakan Etawah (Studi Kasus di Dusun Prodosumbul, Desa Klampok, Kecamatan Singosari, Kabupaten Malang). Ternak Tropika. Journal of Tropical Animal Production. 20(1): 5969.

Mulyawati, I. M., D. Mardiningsih, D. dan Satmoko, S. 2016. Pengaruh Umur, Pendidikan, Pengalaman dan Jumlah Ternak Peternak Kambing Terhadap Perilaku Sapta Usaha Beternak Kambing Di Desa Wonosari Kecamatan Patebon. Agromedia, 34(1).

Murwanto, A. G. 2008. Karakteristik Peternak dan Tingkat Masukan Teknologi Peternakan Sapi Potong di Lembah Prafi Kabupaten Manokwari. Jurnal Ilmu Peternakan, 3(1): 8-15.

Natalia, H., D. Nista, dan S. Hindrawati. 2009. Keunggulan Gamal Sebagai Pakan Ternak. BPTU Sembawa, Palembang.

Nurhayu, A. dan Pasambe, D. 2016. Indigofera Sebagai Substitusi Hijauan Pada Pakan Sapi Potong Di Kabupaten Bulukumba Sulawesi Selatan. Seminar Nasional Peternakan 2, Fakultas Peternakan Universitas Hasanuddin Makassar.

Purbajanti, E. D, Silviana, F. R., dan Benowo, F. E. 2013. Potensi Rumput Gajah (Pennisetum Purpureum's) Untuk Pakan Ternak Sapi Perah di Kecamatan Getasan, Kabupaten Semarang. Prosiding Semnas Agribisnis, Semarang. Kerjasama Ps. Si. Agribisnis L-Pp Undip dengan BPTP Jawa Tengah.

Sari, A. I. 2014. Analisis Keuntungan Peternakan Ayam Ras Petelur Di Kecamatan Mattiro Bulu Kabupaten Pinrang. Faktor-Faktor Yang Berhubungan Dengan Tingkat Adopsi Petani Pada Teknologi Budidaya Padi Sawah Sistem Legowo Di Kelurahan Dusun Besar Kecamatan Gading Cempaka Kota Bengkulu. Jurnal
Agrisep. 06(1).

Ginting, S. P. 2009. Prospek Penggunaan Pakan Komplit Pada Kambing: Tinjauan Manfaat Dan Aspek Bentuk Fisik Pakan Serta Respon Ternak. Wartazoa, 19(2).

Suherman dan E. Kurniawan. 2017. Manajemen Pengelolaan Ternak Kambing di Desa Batu Mila Sebagai Pendapatan Tambahan Petani Lahan Kering. Jurnal Dedikasi Masyarakat, 1(1): 7-13.

Tiro, B. M. W., S. Pramono., H. Hartadi., D. Soetrisno, and E. Baliarti. 2010. The Content of Phytoestrogen of Legume Plants. International Seminar Tropical Animal Production.

Tiro, B. M. W. 2012. Suplementasi Jerami Legum Sebagai Sumber Fitoestrogen untuk Memperpendek Estrus Pertama Pasca Beranak Induk Sapi Silangan Simmental-Peranakan Ongole. Disertasi. Program Pascasarjana. Fakultas Peternakan. Universitas Gadjah Mada.

Yusmadi. 2008. Kajian Mutu dan Palatabilitas Silase dan Hay Ransum Komplit Berbasis Sampah Organik Primer Pada Kambing Peranakan Etawah. Sekolah Pascasarjana Institut Pertanian Bogor, Bogor.

Yusriani, Y., Chairunnas., Helmi, S., dan Asmairecen, S. 2017. Pertanian Bioindustri Berbasis Kedelai dan Kambing di Kabupaten Bireun Provinsi Aceh. Prosiding Seminar Nasional Sinergi dan Sinkronisasi Program Litkaji dan Diseminasi Mendukung Pencapaian Swasembada Pangan.

Yusriani, Y., Chairunnas, dan Asmairecen, S. 2018. Pemanfaatan Sumber Daya Lokal Kedelai-Kambing Dalam Pertanian Bioindustri di Kabupaten Bireun. Bunga Rampai Solusi Pertanian Masa Depan. Badan Penelitian dan Pengembangan Pertanian. IAARD Press, 2018. 
Wijitphan, S., P. Lorwilai, and C. Arkaseang. 2009. Effects of Plant Spacing On Yields and Nutritive Values of Napier Grass (Pennisetum Purpureum Schum.) Under Intensive Management of Nitrogen Fertilizer and Irrigation. Pakistan Journal of Nutrition. 8: 12401243.
Zhang, X., H. Gu., C. Ding, X. Zhong, J. Zhang, and N. Xu. 2010. Path Coefficient and Cluster Analyses of Yield and Morphological Traits in Pennisetum purpureum. Tropical Grasslands 44: 95-102. 